\title{
Dejanira E A Morte No Leito: ConsideraÇões Sobre GÊNERo E Matrimônio Na Tragédia AS Traquínias De Sófocles
}

\author{
Mateus Dagios ${ }^{1}$
}

RESUMO

O objetivo do artigo é analisar o discurso de Dejanira na tragédia As Traquínias de Sófocles. Configuram-se no discurso da personagem trágica questões referentes ao casamento e ao simbolismo do leito para ressaltar uma timé (honra) defendida pela personagem. A análise é feita em uma configuração de gênero no texto trágico que procura localizar uma rede de significados sobre o status da mulher e sua função social para rastrear a tragicidade da personagem, que oscila entre os poderes de Eros e de Afrodite. O artigo atenta para a estrutura da tragédia de Sófocles e para o uso de vocabulário específico que almeja delinear uma Dejanira relacionada ao ô̂kos.

PALAVRAS-CHAVE

Traquínias; Dejanira; casamento; leito; timèe.

1 Doutor em História - Universidade Federal do Rio Grande do Sul (UFRGS). Email: mateusdagios@yahoo.com.br 
Mare Nostrum, ano 2020, v. 11, n. 1 .

Como que sugere a cama

Para quem ama

Palavra quando acesa

Não queima em vão

(Quinteto Violado - Palavra Acesa)

\section{Introdução}

Richard Jebb (1841-1905), um dos símbolos da erudição inglesa no século XIX, em sua introdução à tragédia As Traquínias não se sente constrangido em tecer elogios românticos a Dejanira: “A heroína das Traquínias foi reconhecida por consentimento geral como uma das criações mais delicadamente belas da literatura; e muitos dos que sentem esse charme também sentirão que, tal qual o perfume de uma flor, ele não pode ser descrito" (Jebb, 2010, p. xxxi) ${ }^{2}$. A personagem de Sófocles evoca para a sensibilidade moderna uma postura submissa ${ }^{3}$, um acalento amoroso, que aparentemente não combina com outras mulheres combativas da tragédia como Antígona ou Electra. É um lugar comum nas montagens contemporâneas caracterizar as mulheres da tragédia com grandes reivindicações norteadoras: "Dejanira com o amor, Antígona com a justiça e Electra com a vingança"4 (Mills, 2017, p. 544). A complexidade de Dejanira, como ambicionamos demonstrar, escapa às metáforas de rosas ou à passividade amorosa.

As Traquínias de Sófocles é uma tragédia de contrastes, que tem sua ação desenvolvida em dois tempos, marcando duas cadências, dois espaços distintos, expressão de duas formas diferentes de existir na mesma sociedade. A peça mantém a tradição sofocleana de, segundo Jacqueline de Romilly, opor normas éticas, como Édipo-Tirésias, Odisseu-Filoctetes e Antígona-Creonte (Romilly, 1970, p. 88). Há um consenso entre os mais variados comentaristas da peça em afirmar a existência de

\footnotetext{
2 As citações de textos consultados em língua estrangeira pertencem ao autor.

${ }^{3}$ Para uma compreensão mais alargada da recepção das Traquínias e da figura de Dejanira, ver The Women of Trachis (Mills, 2017). A autora demonstra como a imagem de Dejanira, principalmente na pintura, é mais retratada em seus aspectos míticos com o centauro Nesso e a tentativa de violação do que com aspectos mais textuais da peça.

4 Tradução livre. No original: "Deianeira's in love, Antigone's in justice, and Electra's in vengeance”.
} 
uma estrutura dúplice no texto com duas linhas de ação, a de Dejanira e a de Héracles ${ }^{5}$. A primeira refere-se ao espaço do ô̂kos, ordenado por Dejanira; a segunda, ao espaço guerreiro, de caráter violento, representado por Héracles. No encontro dessas cadências, a trama que liga as ações de Dejanira e de Héracles entrega um desfecho trágico dos dois destinos. Dorothea Wender resumiu assim a relação dessas partes: "Dejanira, a mulher ideal, e Héracles, o homem ideal, não se compreendem, têm objetivos opostos e necessariamente destroem um ao outro (Wender, 1974, p. 02).

As ações de Dejanira são regidas por uma moral cívica, referente a sua situação de esposa e mãe, uma noção de timé (honra) própria ao mundo do lar. Sua ação trágica é fundamentada na ética da pólis em relação a sua condição e o desconforto que pode nos causar uma suposta passividade ou uma brandura romântica não deve ser guia para a compreensão do estatuto da ação de Dejanira. É preciso localizar a origem do seu fundamento em uma teia de relações de gênero que destacam o papel da mulher na configuração social ateniense.

O objetivo do artigo é apresentar uma análise das motivações de Dejanira a partir de uma problemática de gênero. Para isso, será destacado o vocabulário da tragédia que

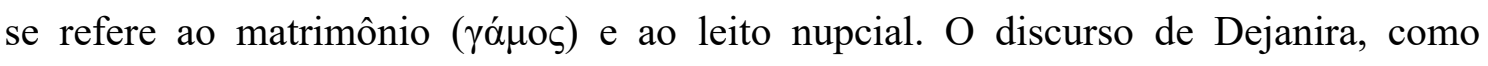
demonstraremos, reivindica sua condição de esposa legítima dentro da paisagem doméstica e seus atos são reivindicação da sua honra.

No quadro teórico, partimos de dois grandes eixos: a contribuição de Nicole Loraux em seus estudos sobre a mulher na tragédia grega e, na esteira do que foi chamado de "Escola de Paris", os textos de Jean-Pierre Vernant, Marcel Detienne e outros pesquisadores alinhados a análises de vocabulário. No que se refere a gênero, partimos do conceito historicizante de Joan Scott de que "(1) o gênero é um elemento constitutivo de relações sociais baseadas nas diferenças percebidas entre os sexos e (2) o gênero é uma forma primária de dar significado às relações de poder" (Scott, 1995, p. 87) para sedimentar uma análise que atente a homens e mulheres dentro de uma rede de poder, na qual diferenças perceptíveis de status e de possibilidades possam ser problematizadas em uma dimensão construída. É preciso salientar que homem e mulher e masculino e feminino são noções culturais e que ideias e características que são tomadas como inatas

\footnotetext{
5 Sobre a estrutura, ver a apresentação de Flávio Ribeiro de Oliveira na sua tradução de As Traquínias (Oliveira, 2009, p. 07).
} 
Mare Nostrum, ano 2020, v. 11, n. 1 .

se desenvolvem ao longo de um processo histórico, que privilegia determinados comportamentos e reprime outros.

Pensar gênero como categoria de análise é almejar escrever uma história na qual sejam protagonizados os papéis sociais nos quais as mulheres não sejam descritas como paisagem dos acontecimentos e nos quais os homens, apesar de deterem a concentração de poder, também possam ser problematizados em seu sistema de representação. Como afirmam Boehringer e Cuchet, "utilizar o gênero como método de análise é, em primeiro lugar, decidir dar tanto espaço às mulheres como aos homens na elaboração das perguntas e dos temas estudados, é promover uma história mista” (Boehringer \& Cuchet, 2011, p. 07). Obviamente que a maneira de encarar as fontes e a escassez dessas no que se refere à Antiguidade se revelam desafiadoras para tal proposta.

Problematizar uma personagem trágica em uma dimensão de gênero é discutir uma rede de significados sociais sobre o que é ser homem ou ser mulher, de acordo com condutas pré-estabelecidas. É importante ressaltar o que definimos como personagem pois, modernamente a noção remete a uma técnica narrativa que toma como princípio noções temporais próprias e psicologizantes de cada obra e de cada autor. Assim, partimos das interpretações de Lucie Thévenet (2009) sobre a personagem trágica grega. Para a autora, as personagens da tragédia se definem por discursos identitários que expõem sua genealogia e a interpretação do mito abordada pelo tragediógrafo. O reconhecimento de si no texto trágico ocorre não só por reivindicações do génos, mas pela enunciação do que se é e do que se passa ou do que se sofre, sendo preponderante para estabelecer a personagem: “dizer sua identidade, dizer a si mesmo na cena trágica, é para a personagem um meio de se afirmar enquanto personagem trágico" (Thévenet, 2009, p. 243). Assim, é defendido que a problemática do casamento e sua relação com o leito são um tópos de identidade explorado por Dejanira em seu discurso.

As Traquínias é uma tragédia que permite, entre outros pontos, investigar aspectos do casamento e do local reservado às mulheres no mundo hierarquizado e segmentado da pólis. Este texto divide-se em duas partes: A trama de Dejanira, em que é explorada a tragicidade de Dejanira, que é levada por uma série de eventos a recorrer a um expediente mágico para defender sua timé de esposa; em A morte no leito, é problematizado o relato da morte de Dejanira como síntese da sua tragicidade e perda da sua honra como esposa, que desfecha seu trágico destino. Por tragicidade compreendemos os motivos ou os percursos que levam a personagem ao seu desfecho trágico, sendo construídos tanto por elementos divinos como por descaminhos humanos. 


\section{A trama de Dejanira}

O enredo da tragédia, de data incerta ${ }^{6}$, aborda o retorno do lendário Héracles. A esposa Dejanira sofre com a ausência de notícias do herói e espera exilada na cidade de Tráquis, acompanhada pelas mulheres da cidade, que formam o coro que nomeia a peça, As Traquínias, e por Hilo, que aguarda notícias do pai. Uma comitiva chefiada por Licas que anuncia o retorno do herói e, juntamente com a jubilosa notícia, traz escravas que foram conquistadas por Héracles. Entre elas, uma jovem de extraordinária beleza e de modos nobres chama a atenção de Dejanira. A identidade dessa jovem acaba sendo revelada por um Mensageiro como sendo Íole, filha do rei da Ecália. O motivo da demorada ausência havia sido a conquista e o saque da cidade de Ecália por parte de Héracles após o rei recusar-lhe a filha como esposa. Dejanira atribui esse ímpeto destrutivo a uma doença do Eros. A heroína reflete sobre seu destino de ser preterida pelo guerreiro em seu leito como esposa. Em uma tentativa de arrebatar o desejo de Héracles e a exclusividade de seu olhar, ela recorre a um expediente mágico, tingindo uma túnica com o sangue do centauro Nesso, que havia sido derrotado por Héracles com seu arco sagrado. $\mathrm{O}$ expediente acaba se tornando um embuste que contamina o herói com uma dor indescritível, uma doença selvagem (ágria nósos) ${ }^{7}$, que o levará à morte. Dejanira retira-se para o quarto e suicida-se. Antes de morrer, Héracles pede para ser queimado no monte Eta e recomenda ao filho que se case com a bela Íole.

A estrutura de As Traquínias, como salientamos, comporta duas grandes partes: a de Dejanira e a de Héracles, personagens que nunca se encontram. Musurillo argumenta que essas duas partes correspondem a um momento da mulher e um do homem no texto, representando espaços distintos da sociedade grega (Musurillo, 1961, pp. 382-3).

É preciso ser cauteloso ao indagar questões de gênero à tragédia grega. Embora seja uma fonte rica para tal problematização, é necessário assumir um olhar específico e estar

\footnotetext{
${ }^{6}$ É preciso salientar que não há nenhum elemento exterior que ajude a precisar a datação da peça. O maior esforço de localização temporal pertence ao artigo de T. F. Hoey The Date of the "Trachiniae". Para o autor, a peça, pelos indícios linguísticos, poderia pertencer à fase tardia de Sófocles, mesmo considerando a presença de um certo estilo arcaico: "o estilo arcaico das Traquínias pode dever-se a uma reversão deliberada por parte de Sófocles na fase tardia de sua carreira" (Hoey, 1979, p. 210).

${ }^{7} \mathrm{O}$ tema da doença na tragédia As Traquínias é muito bem explorado por Charles Segal no artigo Time, Oracles, and Marriage in the Trachinian Women (Segal, 1995) e por Penelope Biggs no texto The disease theme in Sophocles' Ajax, Philoctetes and Trachiniae (Biggs, 1966).
} 
Mare Nostrum, ano 2020, v. 11, n. 1 .

ciente de que é um terreno de significados arenosos. O texto trágico é marcado por relações ambíguas, e a palavra disputa campos semânticos entre o religioso e o jurídico. Jean-Pierre Vernant salienta a singularidade do diálogo trágico: "Entre o diálogo, tal como ele se desenvolve e é vivido pelos protagonistas, interpretado e comentado pelo coro, recebido e compreendido pelos espectadores, há uma defasagem que constitui o elemento essencial do efeito trágico" (Vernant, 1999, p. 19). Nesse mundo de opacidade da linguagem, Nicole Loraux lembra que a dinâmica do palco trágico não é a dinâmica da realidade social: "Não é que na cena trágica seja questionada a realidade da divisão dos papéis sexuais [...]. O discurso trágico, por sua parte, se preocupa pouco em redistribuir o real, mas muito em pensar a distribuição dos valores submetendo-a a todas as distorções possíveis" (Loraux, 1981, p. 57).

A helenista Froma Zeitlin descreve o quanto a ação das mulheres no texto trágico é limitada em níveis de enredo, sendo necessário mediar de forma cautelosa a busca por um feminino na tragédia ou uma forma de ação correspondente ao mundo social:

Mas funcionalmente, as mulheres nunca são um fim em si mesmas, e nada muda para elas depois de viverem seu drama no palco. Ao contrário, elas desempenham os papéis de catalisadoras, agentes, instrumentos, bloqueios, espoliadoras, destruidoras e, às vezes, de ajudantes ou salvadoras das personagens masculinas. Quando representadas de forma elaborada, elas podem servir como antimodelos ou também como modelos ocultos para esse eu masculino, como veremos, e, concomitantemente, sua experiência de sofrimento ou seus atos que as levam ao desastre frequentemente ocorrem antes ou precipitam os dos homens. (Zeitlin, 1985, p. 67)

É preciso lembrar que a escassez de fontes é um problema para análises precisas do mundo antigo. Outra questão que se coloca para quem problematiza gênero na tragédia é o ponto de vista do autor trágico: a tragédia é uma visão masculina da sociedade grega, um texto escrito por homens para uma comunidade de cidadãos. Tal dimensão não anula a potencialidade do texto, mas ressalta sua complexidade e faz emergir representações idealizadas sobre o feminino, sobre posturas normatizantes e desviantes, como explicam Sandra Boehringer e Violaine Cuchet: 
O problema não está no sexo do autor, mas no fato de que essas fontes veiculam principalmente um discurso normativo, isto é, influenciado pela ideologia dos grupos dominantes. Não é porque uma mulher escreve que o texto será necessariamente mais interessante, pois sua proposta poderia ser a mesma de seu marido. O que é interessante para o historiador é ter conhecimento do discurso majoritário e ter acesso igualmente àqueles que saem das normas, que permitem conhecer as práticas e os sentimentos considerados "desviantes" em relação à norma, ou mesmo que permitem acessar outros domínios, também normativos, mas aos quais não se tinha muito acesso, por falta de documentos. (Boehringer \& Cuchet, 2011, p. 27)

Uma análise de As Traquínias permite expor a visão dominante, retratada no discurso da fiel esposa Dejanira, do que se esperava das mulheres nessa sociedade. Ecoam no texto discursos moralizantes. A esposa de Héracles diz: "Estou louca se vitupero meu marido" (Sófocles, As Traquínias, v. 445) ou "Que eu nunca saiba nem apreenda audácias torpes! Detesto mulheres audazes!" (Soph. Trach. 582-583) ${ }^{8}$. O texto trágico é uma fonte que permite observar uma face da ideologia dominante da pólis, mesmo sendo o que Vidal-Naquet definiu como um "miroir brisé", um espelho quebrado, da sociedade ateniense: "cada fragmento remete ao mesmo tempo a essa ou aquela realidade social e a todas as outras, misturando intimamente os diferentes códigos" (Vidal-Naquet, 2002, p. 19).

A tragédia em sua ritualização nas festas dionisíacas e em seu texto é a reflexão de uma questão pertinente à pólis. Em uma máxima famosa, ela é olhar o mito com os olhos de cidadão ${ }^{9}$. A pólis deixa-se interpretar e discute seus contornos. A análise de Dejanira traz à tona algumas demandas do comportamento das mulheres. Como mostraremos, suas

\footnotetext{
${ }^{8}$ Entre as três traduções em língua portuguesa disponíveis, de Maria do Céu Zambujo Fialho (1996), Flávio Ribeiro de Oliveira (2009) e Trajano Vieira (2014), optamos pelo texto de Flávio Ribeiro de Oliveira, que busca uma natureza poética que nem sempre privilegia a métrica, mas com comentários filológicos que explicam e discutem termos com a bibliografia. A edição do texto grego utilizada é a de Flávio Ribeiro de Oliveira (2009).

${ }^{9}$ Para entender essa dinâmica entre pólis e tragédia, dois livros permanecem clássicos: Mito e tragédia na Grécia Antiga (Vernant \& Vidal-Naquet, 1999) e De la tragédie grecque comme art politique (Meier, 2004). As duas leituras são complementares ao estabelecerem vínculos entre a política e o texto trágico.
} 
Mare Nostrum, ano 2020, v. 11, n. 1 .

indagações e sua participação colocam em discussão posturas e obrigações da sua funcionalidade reprodutiva para a pólis. A complexidade da personagem reside na reivindicação de agir sempre dentro das obrigações do casamento, afirmando sua timé e desenvolvendo uma tessitura entre o poder de Eros e de Afrodite na constituição das forças trágicas. Logo nos primeiros versos ocorre a menção ao casamento:

Dejanira:

Quando morava em casa de meu pai Eneu,

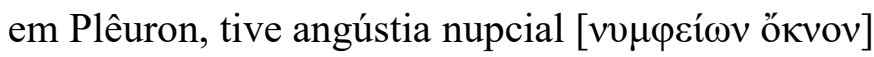

mais pungente que qualquer moça etólia,

pois cortejava-me o rio Aqueloo, (Soph. Trach. 6-9)

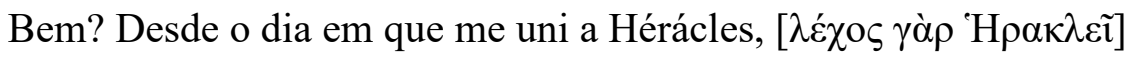

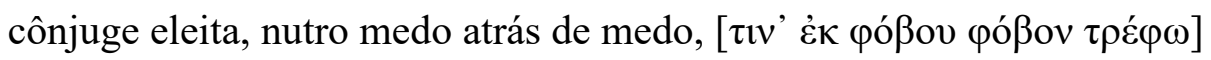

preocupada com ele: noite após noite

tormento vem, tormento vai... (Soph. Trach. 27-30)

Ao escrever sobre a importância da guerra e de rituais de iniciação, Jean-Pierre Vernant defendeu que "o casamento é para a moça o que a guerra é para o rapaz" (Vernant, 2006, p. 26) ${ }^{10}$. Esses acontecimentos definem para o autor a realização da própria funcionalidade do homem e da mulher nesse contexto social. O casamento antigo é um contrato social no qual não é medido nem o amor nem a sexualidade. Modernamente, poderíamos chamar de uma equação de interesses. Um homem deveria se unir a uma mulher para gerar um ô̂kos, e a mulher deveria ser apta a gerar filhos, que seriam futuros cidadãos. Ela deveria gerir a casa e auxiliar no culto doméstico (Boehringer, 2016, p. 24).

\footnotetext{
${ }^{10}$ A frase "le mariage est à la fille ce que la guerre est au garçon" foi largamente discutida e problematizada por Nicole Loraux (1981).
} 
De acordo com Lesley Adkins e Roy Adkins, o casamento em Atenas era monogâmico e a poligamia declarada era considerada um ato de bárbaros (2005). A própria postura de Héracles na tragédia de desejar tomar outra jovem como esposa pode ser interpretada como um ato desmedido. A não contenção dos desejos é uma característica de Héracles bastante explorada em suas representações, principalmente nas comédias, que salientam sua glutonaria ${ }^{11}$. Assim, possuir uma segunda esposa, de origem nobre, não uma concubina, seria um ato reprovado.

O casamento na Grécia pode ser dividido de forma geral em algumas fases: primeiro ocorria o acordo entre o pai e o pretendente; depois, haveria o gámos, que era propriamente a festa; a coroação do casamento era o nascimento de um filho homem, que herdaria os bens do pai e se desenvolveria como cidadão. O gámos era a celebração e tinha um interessante caráter performático e simbólico:

$\mathrm{O}$ evento central de um casamento ateniense era a procissão em uma carruagem simples desde a casa da noiva até a casa do noivo, e os processos judiciais frequentemente citam esse momento como prova da legitimidade de uma esposa. A procissão ocorria tradicionalmente à noite; por isso havia a presença de carregadores de tochas para iluminar o caminho. A noiva, ainda coberta por véu, ficava em pé no carro enquanto o marido montava em preparação para a jornada. Outros parentes seguiam a carruagem a pé, levando presentes para o casal. (Fantham, Foley, Helene, Kampen, Pomeroy, \& Shapiro, 1994, p. 98)

Não havia uma idade mínima para o casamento, mas era arranjado para as mulheres na puberdade. Era comum o casamento entre primos próximos, mas era considerado incestuoso o casamento de filhos de mesmo pai. Na pólis, a mulher era considerada propriedade até em caso de herança: "Em Atenas, uma mulher herdava a propriedade do pai somente se não tivesse irmãos. Mesmo assim, ela não herdava a propriedade, que era legada aos filhos dela por intermédio do marido. Era conhecida como uma epíkleros (herdeira, mas literalmente "vinculada à herança") (Adkins \& Adkins, 2005, p. 444). Não havia legalidade jurídica nas uniões entre escravos e pessoas de status diferentes. Embora

11 Para mais discussões sobre as representações de Héracles na comedia, ver The Boastful Chef: The Discourse of Food in Ancient Greek Comedy (Wilkins, 2000, pp. 90-97). 
Mare Nostrum, ano 2020, v. 11, n. 1 .

os metecos tivessem costumes semelhantes aos atenienses, o casamento entre estrangeiros e cidadãs não era permitido. $\mathrm{O}$ casamento era um ritual de passagem feminino da vida do lar para outra vida como administradora de outra casa.

Dejanira ressalta para as mulheres do Coro a diferença entre ser uma virgem ( $\pi \alpha \rho \theta \varepsilon ́ v o \varsigma)$ e depois ser uma mulher ( $\gamma v v \eta ́)$ :

Dejanira:

Não tens experiências nessas coisas:

a juventude pasce em plagas próprias,

não a perturbam nem calor do sol,

nem chuva, nem ventos;

exulta em aprazível vida sem tormento,

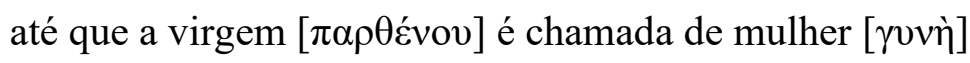

e recebe na noite seu lote de angústias

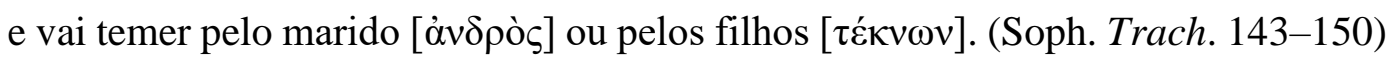

A mulher na dimensão trágica explorada por Dejanira tem em sua existência a obrigação de negociar seu destino entre marido e filhos. A virgem (párthenos), mulher não casada, ocupa no texto trágico um espaço que remete ao sacrifício. Nicole Loraux, em seu provocativo Maneiras Trágicas de Matar uma Mulher, destaca: “elabora-se na tragédia, a propósito das virgens sacrificadas, uma reflexão sobre a condição problemática de parthénos. Reflexão paradoxal que subverte os gestos do casamento submetendo-os ao prisma às vezes muito pouco deformante dos ritos sacrificiais (Loraux, 1988, p. 89). Oferecer uma virgem em sacrifícios é também uma maneira de aplacar um conflito. Maneira simbólica, presente na literatura, pois não existe comprovação de sacrifícios humanos no mundo grego.

Jean-Pierre Vernant ressalta que o casamento era uma forma de acabar com as vendetas familiares: dar uma filha de presente (poinế) transformava, de comum acordo, 
dois grupos inimigos em aliados, que passavam a ser philótes (Vernant, 2006, p. 26). Casamento e guerra relacionavam-se com instituições de paz e propósitos de poder; casar uma filha era fazer uma aliança, arregimentar forças e unir famílias.

As Traquínias demonstra em seu desenrolar a instabilidade das forças de Eros, que desequilibram os interesses da união. A errância de Héracles, ausente segundo Dejanira "há já quinze meses / ele permanece sem dar notícias (Soph. Trach. 44-45), é fundamental para desestruturar a harmonia da união (léchos) ambicionada pela esposa. Loraux destaca sobre o vocabulário de léchos:

Alochos: aquela que compartilha o mesmo leito, léchos. Ou melhor aquela que está vinculada ao leito do esposo, essa instituição. Alochos, léchos: na Grécia das cidades, o leito conjugal não se presta à diversão, pois é lugar-legítimo, para não dizer cívico_-da reprodução. Basta lembrar que o nome da puérpera é léchô e que, em grande parte, o vocabulário do parto (locheuô, Lochia...) é constituído por derivação em torno de lochos, o lugar em que a pessoa se deita. Os fatos da língua às vezes ensinam muito sobre uma sociedade. (Loraux, 1981, p. 41)

A angústia do leito vazio e da longa espera de Dejanira é destacada pelo coro:

Coro:

Soube que, saudosa no peito,

a disputada Dejanira

como ave triste

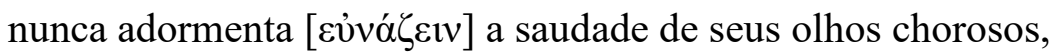

mas, com medo memoroso da ausência do marido,

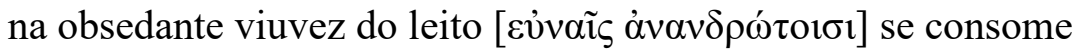

a esperar funesto fado. (Soph. Trach. 103-111) 
Mare Nostrum, ano 2020, v. 11, n. 1 .

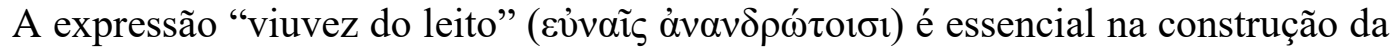
tragicidade de Dejanira. O coro descreve o leito como centro da vida da personagem. $\mathrm{O}$ leito vazio é o símbolo dessa união que não se completa pela errância de Héracles. Patricia Easterling interpreta esses versos como uma inversão da ordem: “Talvez a implicação seja que, enquanto na ordem natural das coisas o dia segue a noite e a noite segue o dia, a forma de vida de Dejanira viola o ritmo natural" (Easterling, 1968, p. 59). A solidão do leito de Dejanira coloca-se nesse momento do texto como cerne da tragicidade do discurso da personagem.

A partir do relato do Mensageiro, que corrige as mentiras de Licas, sobre o que realmente motivou a longa ausência do esposo de Dejanira, temos a inserção do poder de Eros na peça, atuando sobre Héracles e Dejanira. Eros é citado quatro vezes (Soph. Trach. 354, 433, 441, 489), sempre evocando uma força que não mede consensos, agindo pela voracidade e desrazão. A primeira referência surge quando o Mensageiro conta o real motivo da ausência prolongada de Héracles:

Mensageiro:

Eu escutei este homem dizendo,

com muitas testemunhas presentes,

que foi por causa dessa moça que Héracles

arrasou Êurito e a altimurada Ecália,

e que só deus Eros [’E $\rho \omega \varsigma]$ o induziu a brandir lança -

não o penoso serviço prestado na Lídia a Ônfale. (Soph. Trach. 351-355)

O mesmo Mensageiro, dirigindo-se a Licas para desmenti-lo, reafirma o poder de

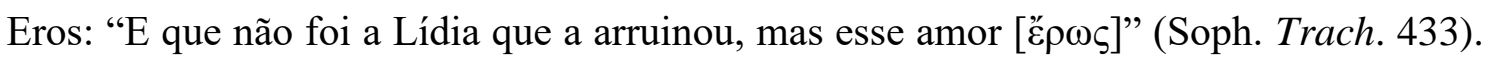
O relato do poder de Eros é suficiente para Dejanira não culpar o marido, mas atribuir a essa força exterior que o dominou a responsabilidade pelos seus atos, tornando-o um enfermo, um doente de Eros:

Dejanira: 
Quem, como um pugilista, trava luta contra

Amor [’E $\rho \omega \tau \imath]$ não raciocina bem.

Amor governa os deuses como quer — e a mim também -

e por que não também uma outra como eu?

Estou louca se vitupero meu marido,

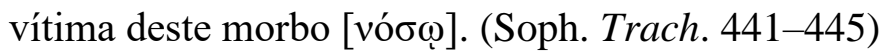

Ao descrever o poder de Eros sobre Héracles, Dejanira não está abrandando os atos do esposo, ou ainda o que modernamente poderíamos descrever como um autoengano sobre a postura de Héracles. Ela está descrevendo uma prática comum dos poderes dessa força inebriante de Eros: "Trata-se de um estado que transforma profundamente o indivíduo, uma espécie de invasão, amiúde associado ao sono profundo, à morte, a um nevoeiro que tudo encobre, à embriaguez que perturba os sentidos" (Boehringer, 2016, p. 17). Na poesia arcaica, Eros não é uma força ordenadora e tampouco refúgio prazeroso para quem é acometido por seus encantos: “a imagem mais recorrente na época arcaica é aquela de um érôs devastador que, uma vez que atinge o ser apaixonado, destrói tudo o que se encontra no seu horizonte" (Boehringer, 2016, p. 15).

Ao descrever a força de Eros como um "pugilista" ( $\pi v ́ \kappa \tau \eta \varsigma)$ e a inutilidade de lutar com tal força, Dejanira realça ainda mais a solidão do seu leito, pois a incapacidade de medir astúcia com o desejo faz a ausência de Héracles ainda mais penosa à esposa. A "viuvez no leito" é um sentimento do poder de Eros, da ausência que ecoa no discurso de Dejanira. De acordo com Várzeas, “a ironia maior dessa tragédia é que a sabedoria e a sensatez de Dejanira fazem dela a personagem de quem menos se esperava a habitual irracionalidade das manifestações de eros" (Várzeas, 2009, p. 22).

A última ocorrência de Eros na peça é o momento que ocorre antes de Dejanira colocar seu plano em ação. É necessário atentar para a tragicidade do discurso: 
Mare Nostrum, ano 2020, v. 11, n. 1 .

Licas:

Mas agora que conheces toda a história,

para o bem dele e também para o teu

aceita essa mulher, e que as palavras que disseste

a seu respeito estejam ditas firmemente.

Pois todo o resto ele supera com a força,

mas o derrota totalmente o amor que tem por ela. (Soph. Trach. 484-489)

Licas garante à fiel e nobre esposa que Héracles, o mais excelente guerreiro, possuidor de armas sagradas, o mais forte dos homens, realizador de trabalhos impossíveis, não pode e nem vencerá o poder de Eros. Se a tragicidade da peça se apresentava anteriormente na errância de Héracles, que era responsável pela solidão da personagem, passa a ser o poder de Eros sobre o invencível Héracles. A solidão da esposa é completamente impotente e a situação compromete ainda mais sua honra.

Dejanira passa então a armar um plano, que escapa à sua natureza de esposa, mas que parece ser a única salvação para recuperar sua timé. Enquanto Dejanira se retira, o coro entoa um canto contando as proezas de Afrodite e a disputa pelo leito de Dejanira entre Héracles e o rio Aqueloo ${ }^{12}$, que se apresentava sob três formas para cortejá-la, ora visível como um touro, ora uma serpente sinuosa e depois um homem com cabeça de boi sem chifres:

Coro:

Magna potência é Cípris: sempre vence.

Os deuses omito:

12 Sobre a forma do rio Aqueloo, ver o artigo The Hydra Nursling: Image and Action in Trachiniae de Charles Segal (1975). Para o autor, a figura do Rio representa uma força destrutiva da violência que ambos enfrentaram para estabelecer uma ordem civilizacional com o casamento (Segal, 1975, p. 615). 
como enganou o Crônida não digo,

nem Hades, o noturno

ou Posídon, que faz tremer a terra.

Mas, para ter como esposa Dejanira,

que portentos contenderam por tais núpcias?

Quem travou liças

pugnaces e pulverosas?

Um era a potência de um flume

Na forma de alticornígero touro quadrúpede,

Aqueloo de Eníades,

o outro veio da báquica Tebas

a brandir arco curvo e clava e hastas,

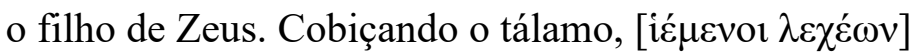

lançaram-se ambos em luta cerrada;

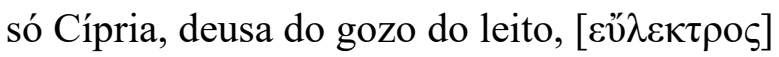

tinha no centro o cetro arbitral. (Soph. Trach. 497-516)

Referida como Cípria, Afrodite é uma divindade ligada aos poderes da persuasão (peithō). Marcel Detienne ressalta que existe uma peithō ligada à persuasão amorosa e que Afrodite elabora uma relação entre ternura (philotés), desejo (himeros) e as conversações amorosas (oaristis), todas envolvidas nos jogos de sedução (Detienne, 1988, p. 38). A dualidade da persuasão de Afrodite está na relação da peithō positiva e da peithō negativa: a trama positiva que associa Afrodite, a mulher sorridente, à palavra de 
Mare Nostrum, ano 2020, v. 11, n. 1 .

sedução, Peithō e Apaté (engano) sob seu aspecto benéfico, equivale a uma trama negativa, na qual cada um desses termos possui seu correspondente negativo (Detienne, 1988, pp. 38-39).

O coro de mulheres ressalta o poder de Afrodite Cípria, descrita em seu epíteto como "deusa do gozo do leito" ( $\varepsilon u ̋ \lambda \varepsilon \kappa \tau \rho \circ \varsigma)$ para ressaltar mais uma vez o papel do leito incompleto na tragicidade de Dejanira. Claude Calame destaca a importância do leito na poesia grega arcaica:

Na mitologia, um leito é essencialmente uma metáfora para uma união entre dois jovens adultos. Como realidade institucional, tal leito era descrito como homophrôn, pois “unia sentimentos". Em um contexto matrimonial, Safo expressou o desejo de que tal leito fosse "mais jovem" para um amigo (philos) que era mais jovem que ela. E em um leito assim se geravam filhos, mesmo se a esposa fosse estrangeira. Somente os seres primordiais Deucalião e Pirra não precisaram de um leito (lekhos) para gerar a raça de pedras que deu origem à raça humana. (Calame, 1992, p. 35)

A descrição da luta entre o rio Aqueloo e o filho de Zeus, Héracles, refere-se à disputa pelos encantos de Dejanira, que, pela errância e pela desmedida de Héracles, atualmente compartilha leito apenas com o desejo e não com o esposo.

Os encantos de Afrodite, como alerta Claude Calame, podem vir acompanhados por vários companheiros que desenvolvem o enredo da relação, como Dionísio, Eros e as Ninfas (Calame, 1992, p. 32). O autor ressalta uma conexão entre Eros e Afrodite, que na poesia grega são descritos em simetria: “Afrodite geralmente age por meio da mediação desses outros poderes do desejo, mas às vezes ela intervém diretamente, e com os mesmos efeitos atribuídos a Eros" (Calame, 1992, p. 32). O poder de Eros conecta-se ao poder de Afrodite e tal união produz uma série de metáforas referentes ao leito.

Consciente da sua vulnerabilidade diante das forças divinas e do poder de Eros que adoece a mente de Héracles, Dejanira age contra os princípios de esposa, tramando um plano para ser a única mulher reinante no leito de Héracles, mas antes de detalhar a trama, ela resume ao coro toda a tragicidade da sua situação: 
Dejanira:

Pois não foi uma moça, mas uma mulher

que acolhi, como excesso de carga em navio,

mercadoria que me humilha o espírito.

E agora nós duas, sob um só lençol,

esperamos abraços: eis a vida doméstica

que meu fiel e honesto Héracles

me legou como prêmio por tão longa ausência!

Não sou capaz de me irritar com ele,

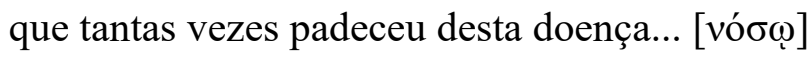

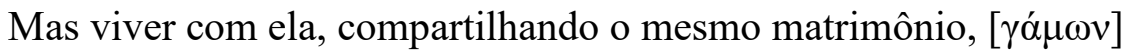

que mulher conseguiria?! (Soph. Trach. 536-546)

A personagem expõe seu descontentamento com acolher outra mulher para dividir o espaço de esposa do mesmo marido. A nobre Dejanira fora ofendida em sua timé: ausente de casa, em país estrangeiro, sofre uma humilhação em seu gámos que não condiz com seu status. Jean-Pierre Vernant explica que no âmbito da disparidade nas relações entre homens e mulheres, a honra era o parâmetro que mantinha a estabilidade do casamento:

O estatuto das mulheres, assim como dos filhos legítimos ou bastardos, depende então em grande parte da timée, a honra que lhe é concedida pelo chefe da família. E sem dúvida esse último não é livre, nesse plano, para fazer inteiramente a sua vontade. Uma mulher de grande nobreza a quem foi preciso ganhar ao preço de custoso lance de hédna, e que representa, pelo círculo de dotes e contradotes 
Mare Nostrum, ano 2020, v. 11, n. 1 .

provocados pelo casamento, um compromisso de aliança entre duas famílias poderosas, não poderia sem inconveniência ser tratada da mesma forma que uma menina comprada ou uma cativa de guerra. (Vernant, 2006, p. 80)

É importante ressaltar que a configuração da questão não é somente de poligamia sexual, pois por mais que o casamento fosse monogâmico, havia filhos bastardos e situações que não são facilmente compreendidas em nossa moral. Héracles traz para casa uma mulher tão nobre quanto Dejanira para com as duas compartilhar o leito. Assim, a desmedida do herói afeta a harmonia do ô̂kos. Dejanira é duplamente humilhada em sua honra de esposa e em seus desejos. Consciente da sua vulnerabilidade diante das forças divinas e do poder de Eros que adoenta a mente de Héracles com a nósos, Dejanira trama seu plano com o sangue mágico do centauro:

Dejanira:

Lembrei do sangue, amigas

(após a morte de Nesso, guardei-o bem em casa),

e nele embebi esta túnica, seguindo as instruções

que ele me dera. E isto está feito.

Que eu nunca saiba nem aprenda

audácias torpes! Detesto mulheres audazes!

Mas se eu puder vencer esta garota

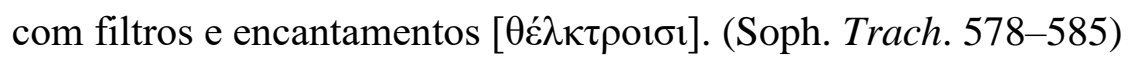

A trama de Dejanira é um encantamento ( $\theta \varepsilon \lambda \kappa \tau \eta ́ p ı v)$, um artifício. Acreditando nas palavras do centauro, ela faz um procedimento de mistura do sangue envenenado para colorir uma túnica, pois de acordo com Nesso, a astúcia garantiria que Héracles só teria olhos para ela. Pozzi afirma que a túnica é um símbolo ambivalente das forças de Eros 
que percorrem a peça (Pozzi, 1994, p. 581). Se a doença de Eros fez Héracles ser desmedido, a ambição de domar o Eros fará Dejanira ter um fim trágico.

O sangue de Nesso é definido como um phármakon: "Eis o que me foi ordenado, e

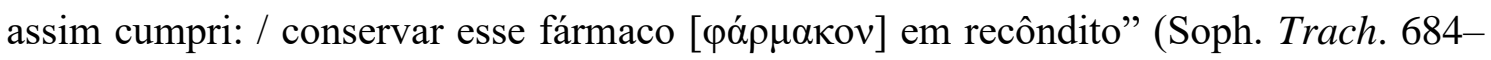
685). O phármakon atua como um apaziguador, um agente controlador e um corretor de sintomas. Recorrer a ele não é recorrer a um bálsamo, mas desejar um efeito que não é somente de cura, mas também de encantamento. A ideia do expediente mágico para conquistar os favores de Eros ou o encantamento do parceiro era comum no mundo grego. Christopher Farone, no seu Ancient Greek Love Magic, destaca um grande número de rituais e encantamentos para a proteção das forças de Eros e de Afrodite (Farone, 2001, p. 60). Para o autor, o expediente de Dejanira não era compreendido como algo que ultrapassasse certa normalidade dos jogos e disputas amorosos:

Se o público ateniense entendia que os venenos eram comumente administrados em pequenas doses aos homens como poções do amor, então sua culpa em empregar conscientemente o sangue venenoso do centauro é de certo modo mitigada, pois Dejanira parece usar um remédio tradicional para o amor perdido de uma maneira que não era ilegal na Atenas clássica. (Farone, 2001, p. 118)

A trama de Dejanira é a resposta à tragicidade da sua situação, que na disputa com a jovem Íole, será preterida como esposa e perderá seu prestígio na esfera do ô̂kos. A desmedida de Héracles atinge a timé da esposa, mas as duas mulheres são vítimas da insaciedade de Héracles: Dejanira perde seu lugar de esposa, enquanto Íole perde sua família e seu lar. É possível perceber o quanto as mulheres são alocadas e realocadas conforme um arranjo masculino, e qualquer resposta a tal situação coloca a ação feminina em um terreno de transgressão da ordem. A ação de Dejanira sofre então uma reviravolta que sela os destinos do casal.

\section{Dejanira e a morte no leito}

A morte na tragédia é sempre representativa. Ela não é apenas desfecho, mas parte de um itinerário simbólico. O itinerário de Dejanira termina no local em que reivindicou sua honra do lar, local que centralizou sua experiência trágica e ordenou suas narrativas: 
Mare Nostrum, ano 2020, v. 11, n. 1 .

o leito. O fim da personagem pode ser compreendido como uma reviravolta, mas também pertence a uma trama de oráculos e profecias que envolve a todos em uma teia silenciosa. A nutriz conta ao coro o que presenciou:

Nutriz:

Foi tétrico! Mas saberás, para que sejas minha testemunha.

Quando sozinha adentra a casa e vê seu filho

a preparar no pátio um cavo catre

para de novo defrontar o pai,

ela se abriga onde ninguém a veja

e, prosternando-se em frente aos altares,

brada que fora desertada e chora

ao tocar cada objeto que outrora usara, a pobre! (Soph. Trach. 899-906)

Dejanira isola-se ao saber que sua artimanha resultara na morte do esposo. Se antes a tragicidade se abatia sobre sua honra, com a morte de Héracles, sua timé está totalmente destruída aos olhos dos cidadãos. Nicole Loraux argumenta que o suicídio, embora fosse socialmente reprovado, é na tragédia uma forma heroica de morte própria das mulheres: “Achar uma saída no suicídio: solução trágica reprovada pela moral na confusão da vida cotidiana. Mas, principalmente, solução de mulher e não, como às vezes se pretendeu, ato heroico" (Loraux, 1988, p. 37), uma solução do homem trágico. É difícil rastrear o heroísmo em um ato como o do suicídio, mas na configuração de uma sociedade que pensa ser o silêncio ornamento das mulheres, o suicídio é um tipo de escolha que retira dos outros o protagonismo de uma ação de morte sob o estigma de uma suposta culpa.

O relato da nutriz pontua o fato de Dejanira, sem seu marido, não poder mais ter filhos, salientando o papel da mulher dentro da esfera do casamento: 
Nutriz:

Rodando por cada canto da casa,

toda vez que enxergava algum dos caros servos

começava a chorar a desgraçada ao vê-lo

e ela mesmo evocava seu próprio destino

e o fato de não mais ter filhos doravante. (Soph. Trach.907-911)

O casamento, como já salientado, era um evento central na vida de uma mulher no mundo grego clássico, e a lógica do casamento não era outra além da reprodução. Ao evocar o fato de não poder mais ter filhos, estando ela no leito, salienta-se a morte da sua função social dentro do casamento. A pressão social por filhos não era algo ocasional; havia, como nos mostra Sue Blundell, uma vigilância dos cidadãos para que o casamento gerasse filhos e a transmissão da cidadania fosse legítima:

A seriedade com que os homens viam os direitos e as responsabilidades exercidos pelas mulheres como outorgadoras da cidadania é ilustrada pelo famoso caso contra Neera, apresentado nas cortes atenienses em cerca de 340 a.C. Em um discurso atribuído a Demóstenes, dois homens processam Neera, uma cortesã coríntia, por viver com um cidadão ateniense Estéfano como sua esposa, de forma contrária às leis de Atenas. Uma das principais acusações feitas durante esse caso é que Estéfano teria apresentado os filhos estrangeiros de Neera como seus próprios filhos de um casamento anterior e havia duas vezes dado a filha dela em matrimônio a cidadãos atenienses: qualquer criança nascida em decorrência disso teria exercitado fraudulentamente os direitos de cidadania. (Blundell, 1995, p. 121)

A nutriz descreve em detalhes como Dejanira, em desespero, invade o quarto, em uma parte carregada de simbolismo. O quarto que antes estava vazio pela errância de Héracles, permanecerá vazio. A presença da bela Íole não se configura mais um problema, 
Mare Nostrum, ano 2020, v. 11, n. 1 .

nem mesmo é lembrada. Todos os motivos de angústias foram suplantados por um motivo ainda mais atroz. Dejanira não é mais a esposa de Héracles, mas sua assassina. O leito, testemunha da sua angústia, será também o lugar da sua morte.

Nutriz:

Quando cessou, a vejo de repente

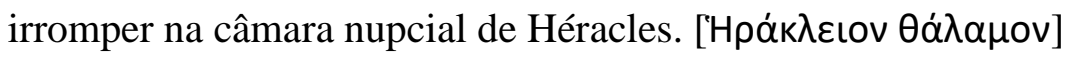

Eu vigiava com olhar furtivo,

Escondida: percebo a mulher

estendendo lençóis na cama dele

e, tão logo termina, salta e senta

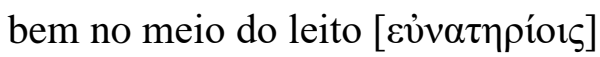

e verte fluxos cálidos de lágrimas

dizendo: “ó câmara e tálamo meus,

agora é para sempre adeus, pois nunca mais

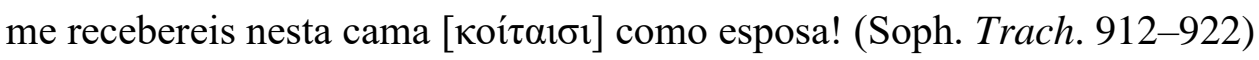

Nicole Loraux lembra que na tragédia "não há morte de mulher que não passe pelo leito" (Loraux, 1988, p. 52). A afirmação é provocativa: não se refere somente ao Locus Mortis, mas também ao fato de a existência das mulheres na tragédia ser sempre definida em relação à vida de um homem. A morte no leito é, assim, icônica da situação das mulheres no mundo grego. O quarto nupcial (thálamos), lugar de recolhimento, é o local em que Dejanira se refugia para a morte: "se o thálamos é a parte mais recôndita da casa, há ainda no interior do thálamos o leito, léchos, lugar de um prazer tolerado pela instituição do casamento se for bastante moderado, lugar sobretudo da procriação (Loraux, 1988, p. 52). A morbidez da cena não deixa de evocar um certo erotismo, um desnudamento antes da morte: 
Nutriz:

Sem mais dizer, com mão enérgica

desata o peplo que sobre o seio

fixava broche aurilavrado

e despe todo o flanco e braços esquerdos.

Eu parto o mais veloz que posso

e explico a seu filho o que ela tramava.

Foi só o tempo de ir e vir,

e a vemos ferida no flanco por bigúmeo gládio

fundo no fígado e no diafragma. (Soph. Trach.923-931)

Nicole Loraux pontua o significado do ferimento no diafragma e as relações entre reprodução e morte guerreira: "nessa região do corpo em que os golpes são mortais, ali onde são golpeados os guerreiros, onde Ájax afunda seu gládio, onde o Héracles de Eurípides queria apoiar seu punhal, ali por fim onde uma mulher leva seu filho — sob o fígado, sob essa "cintura" que é o diafragma” (Loraux, 1981, p. 66).

A dualidade de Dejanira é colocada na própria ação da morte no leito. De acordo com Edwin Carawan, "o suicídio dela é o gesto final em uma caracterização construída para tornar o julgamento da culpa ou inocência difícil e perturbador” (Carawan, 2000, p. 219). Tal ação nos coloca diante da dificuldade de uma análise de gênero.

Dejanira foi destituída de toda a sua timé. Não há paradeiro social, não há compreensão discursiva e nem reestruturação possível dentro do seu mundo. Se era vítima de um marido ausente e reivindicava uma existência condizente com seu status e função de mulher grega, ela passou a ser a pior das mulheres por ter assassinado seu esposo. A morte no leito é um consolo do inconsolável, e destino e ato humano se tramam e tecem o fim de Dejanira. A Corifeia dará então um aviso às outras mulheres do Coro, lembrando a todos os espectadores o poder de Zeus: 
Mare Nostrum, ano 2020, v. 11, n. 1 .

\section{Corifeia:}

Viste mortes inéditas, medonhas,

e muitos e insólitos tormentos:

e disso tudo não há nada que não seja Zeus. (Soph. Trach. 1276-1278)

Zeus teceu o caso de Dejanira com os fios do desejo de Eros, trançados aos fios dos encantos de Afrodite. Os mesmos fios que teceram o leito vazio se entrecruzaram para tecer a túnica envenenada e como resultado entregaram também um leito banhado em sangue. Os atos humanos em seus descaminhos mais uma vez encontraram a ordem dos caminhos de Zeus.

\section{Conclusão}

Rastrear as ações de Dejanira em relação ao matrimônio (gámos) é estratificar níveis de tragicidade. A personagem é um ponto privilegiado para observar questões sobre gênero e os deveres atribuídos à mulher na pólis. Tentamos demonstrar que o discurso de Dejanira é reivindicador de sua honra, de sua timèe. O leito, recorrente na peça, é não apenas símbolo do matrimônio, mas é o lugar de desfecho e espaço de significação dos deveres femininos.

Dejanira principia a peça ressaltando a tragicidade do matrimônio, que traz à virgem os problemas do marido e dos filhos. Depois, acompanhamos a solidão e um casamento incompleto, seguimos a humilhação da nobreza de Dejanira ao ser apresentada a uma princesa que vem dividir o leito do esposo e, consequentemente, compartilhar seu status no oîkos. A personagem acaba recorrendo a artifícios que não fazem parte de sua natureza, tramando com Eros por Héracles. A situação em sua reviravolta traz a pior das consequências e o leito serve como túmulo da esposa.

As Traquínias expõe o que se esperava das atenienses: passividade e obediência ao esposo. Outros meios de ação poderiam causar reviravoltas e consequências graves. Os atos de Dejanira buscam a normalidade do matrimônio, mas ela não age por passividade ou por sentimentos que modernamente ligaríamos aos poderes do coração. O que está em jogo é sua honra, sua obrigação de ter filhos e de dividir o leito com Héracles, sua posição 
no ô̂kos. Como salientamos, ambicionar fazer uma análise de gênero no texto trágico exige considerar uma rede de significados. O leito é um dos símbolos da união. Sófocles problematiza o leito como elemento central e a partir dele, podemos compreender a união ligada a Eros e à reprodução como fim do casamento.

Problematizar uma tragédia é fazer escolhas perante indícios. Privilegiamos o matrimônio e o leito na configuração do trágico e de elementos sociais relacionados às obrigações femininas. Se, analisado Héracles, outros indícios seriam proeminentes, além das questões do oráculo e da doença, Dejanira, como demonstramos, evoca uma rede de percepções sobre o casamento e de posturas de gênero que escapam à nossa sensibilidade moderna.

Recebido em 21.01.2020, aprovado em 01.05.2020. 
Mare Nostrum, ano 2020, v. 11, n. 1 .

\section{REFERÊNCIAS BIBLIOGRÁFICAS}

Adkins, L., \& Adkins, R. (2005). Handbook to Life in Ancient Greece. Facts On File.

Biggs, P. (Oct. de 1966). The Disease Theme in Sophocles' Ajax, Philoctetes and Trachiniae. Classical Philology, 61(4), 223-235.

Blundell, S. (1995). Women in Ancient Greece. Harvard University Press.

Boehringer, S. (2016). A sexualidade tem um passado? Do érôs grego à sexualidade contemporânea: questionamentos modernos ao mundo antigo. Bagoas (15), 14-32.

Boehringer, S., \& Cuchet, V. S. (2011). Hommes et femmes dans l'Antiquité grecque et romaine. Colin.

Calame, C. (1992). The Poetics of Eros in Ancient Greece. Princeton University Press.

Carawan, E. (2000). Deianira's Guilt. Transactions of the American Philological Association, 189-237.

Detienne, M. (1988). Os Mestres da Verdade na Grécia Arcaica. Jorge Zahar.

Easterling, P. E. (1968). Sophocles, Trachiniae. Bulletin of the Institute of Classical Studies(15), 58-69.

Fantham, E., Foley, Helene, P., Kampen, N. B., Pomeroy, S. B., \& Shapiro, H. A. (1994). Women in the Classical World: Image and Text. Oxford University Press.

Farone, C. A. (2001). Ancient Greek Love Magic. Harvard University Press.

Hoey, T. F. (Autumn de 1979). The Date of the "Trachiniae". Phoenix, 33(3), 210-232.

Jebb, R. (2010). Introduction. In Sophocles, Sophocles, Vol. 5: The Plays and Fragments, With Critical Notes, Commentary, and Translation in English Prose; The Trachiniae (pp. IX-L). Cambridge University Press.

Loraux, N. (1981). Le Lit, la guerre. L'Homme, 21(1), 37-67.

Loraux, N. (1988). Maneiras Trágicas de Matar uma Mulher: Imaginário da Grécia Antiga. Jorge Zahar.

Meier, C. (2004). De la tragédie grecque comme art politique. Les Belles Lettres. 
Mills, S. (2017). The Women of Trachis. Em R. Lauriola, \& K. N. Demetriou, Brill's Companion to the Reception of Sophocles (512-557). Brill.

Musurillo, H. (1961). Fortune's Wheel: The Symbolism of Sophocles' Women of Trachis. Transactions and Proceedings of the American Philological Association, 92, 372383.

Oliveira, F. R. (2009). Apresentação, introdução e comentário filológico. Em Sófocles, As Traquínias. (Ed. bilíngue). Editora da Unicamp.

Pozzi, D. C. (Nov. de 1994). Deianeira's Robe: Diction in Sophocles' "Trachiniae". Mnemosyne, 47 (5), 577-585.

Romilly, J. d. (1970). La Tragédie Grecque. PUF.

Scott, J. (jul./dez de 1995). Gênero: uma categoria útil de análise histórica. Educação \& Realidade, 20 (2), 71-99.

Segal, C. (1975). The Hydra Nursling: Image and Action in Trachiniae. L'antiquité classique, 44 (2), 612-617.

Segal, C. (1995). Sophocles' Tragic World: Divinity, Nature, Society. Harvard University Press.

Sófocles. (1996). As traquínias. (Zambujo Fialho, Maria do Céu, trad). UnB.

Sófocles. (2009). As Traquínias. (Apresentação, introdução e comentário filológico de Flávio Ribeiro de Oliveira). (Ed. bilíngue). Editora da Unicamp.

Sófocles. (2014). Sófocles / As Traquínias. (T. Vieira, trad.). Ed. 34.

Thévenet, L. (2009). Le personnage : du mythe au théâtre. La question de l'identité dans la tragédie grecque. Les Belles Lettres.

Várzeas, M. (2009). Amor e amizade em Sófocles. Em B. Pereira, \& J. Deserto, Symbolon I: Amor e Amizade (19-29). FLUP.

Vernant, J.-P. (1999). Tensões e ambiguidades na Tragedia Grega. In Vernant, J. P. \& Vidal-Naquet P., Mito e tragédia na Grécia Antiga (7-24). Perspectiva.

Vernant, J.-P. (2006). Mito e sociedade na Grécia antiga. José Olympio.

Vernant, J.-P., \& Vidal-Naquet, P. (1999). Mito e tragédia na Grécia Antiga. Perspectiva. 
Mare Nostrum, ano 2020, v. 11, n. 1 .

Vidal-Naquet, P. (2002). Le Miroir brisé. Tragédie athénienne et politique.Les Belles Lettres.

Wender, D. (1974). The will of the beast: sexual imagery in the Trachiniae. Ramus, 3 (1), $1-17$.

Wilkins, J. (2000). The Boastful Chef: The Discourse of Food in Ancient Greek Comedy. Oxford University Press.

Zeitlin, F. (Summer de 1985). Playing the Other: Theater, Theatricality, and the Feminine in Greek Drama. Representations (11), 63-94. 
Mateus Dagios. Dejanira e a morte no leito.

\section{DEIANIRA AND THE DEATH IN BED: GENDER AND MARRIAGE IN SOPHOCLES'WOMEN OF TRACHIS}

\section{Mateus Dagios}

\section{ABSTRACT}

This study analyzes Deianeira's discourse in Sophocles' Women of Trachis, examining issues related to marriage and the symbolism of the marital bed to establish a timé (honor) advocated by the tragic character. The analysis builds on a gender studies approach to Greek tragedy that seeks to locate a network of meanings about the status of women and their social function in order to track the character's tragicity, oscillating between the powers of Eros and Aphrodite. The study examines the structure of Sophocles' tragedy and his use of specific vocabulary to delineate a Deianeira connected to the ốkos.

\section{KEYWORDS}

Women of Trachis; Deianeira; marriage; bed; timé. 